\title{
TED talk as a simulation tool in a higher education for the learning process and improvement students' motivation: an academic practice with students of the Degree in Business Intelligence and a prospective
}

\author{
Sanchidrian Pardo Rosa ${ }^{a}$, Yubero Hermoso Pilar ${ }^{b}$, Torrente Barredo Begoña ${ }^{c}$ \\ ${ }^{a}$ Universidad San Pablo CEU, Madrid, España, maria.sanchidrianpardo@ceu.es, Phd ${ }^{\text {b Universidad }}$ \\ San Pablo CEU, Madrid, España, yubher@ceu.es; Phd, ${ }^{\mathrm{c}}$ Universidad San Pablo CEU, Madrid, \\ España, begona.torrentebarre@ceu.es, Phd.
}

\begin{abstract}
The main mission of this project is to improve the professional skills of first year students and to measure their motivation, focus on self-learning and professionalism. For that, the professor uses The TEDxtalks methodology as a great tool to develop these essential competences and introduces the student as the protagonist of the self-learning process. The TEDxtalks tool was created to disseminate scientific results of great researchers. It has now become a system of scientific and social dissemination, used to improve formal and informal learning. Also, one of the skills that Spanish people need to work on is their communication skills and these kinds of projects are based on the effective communication competences and others that increase the motivation of students to self-learn and ask about newly acquired knowledge.This educational innovation project tries to use these tools to improve the professional and academic skills and reinforce the human dimension of students and the factor to motivate them to study and learn. It has been evaluated and with the advice of a mentor (subject teacher). The project has been evaluated using a quantitative and qualitative method and the conclusions are interesting because the students recommend it and indicates that their has been an improvement on skills, motivation, values and knowledge.
\end{abstract}

Keywords: Higher education, Bolonia process, innovation, academic practices, new methologies, self-learning, professional skills and compentences, Tecnology Education, spread ideas, motivations. 
Ted talks as a simulation tool in a higher education for the learning process and improvement students' motivation : an academic practice with students of the Degree in Business Intelligence.

\section{Introduction}

According to the goals of the Bolonia process, the main mission of this project is to start the develop the professional skills of first year students and to measure student's motivation to use the practice of TEDxtalks as a self-learning tools. For that, the professor uses TEDxtalks methodology as a key tool to develop the main new demanding competences and focus on the student like the protagonist of the self- learning process. The TEDxtalks tool was created to disseminate scientific results of great researchers. It has now become a system of scientific and social dissemination, used to improve formal and informal learning. Internet, the new Social Technology Network and platforms, as YouTube, had been managed to open new channels to facilitate massive learning, examples like MOOCs,TEDs and University Channels in YouTube, blogs and other educational platforms. Moreover, one of the skills that Spanish people need to work on is the communications skills and these kinds of projects are based on the effective communication competences, and others that increase the motivation of students to self-learn and ask about new knowledge.

This innovation project tries to use these tools and has several objectives. On the one hand, it aims to increase their motivation. On the other hand, it brings students closer to research studies, while improving their professional skills. Lastly, it has sought to reinforce the human dimension of the students, learning competencies, also values such as respect, ethics, commitment and excellence. All of these activities have been evaluated with the advice of a mentor. Using a quantitative and a qualitative method, the results are interesting because the students approve of the use of practices in the classroom to elaborate and present their TEDxtalks and improve skills, motivation, values and knowledge.

\section{New Higher education practices: a TEDxtalks simulation as a tools to improve the skills and students motivation.}

\subsection{The Challenges of Bolognia at the present time.}

\subsubsection{The context of Bolognia Process}

More than two decades ago, the Bologna Declaration established the objectives of the socalled Bologna Plan that sought to modernize the European Higher Education System (EHES) based on a formal convergence. The Bologna Declaration made Europe rethink its teaching methodology and the learning and teaching process. The objectives for the 21 
centuries were to adapt them to the new academic objectives and the competences that the students should acquire. Until 2010, the Bologna Process, as well as the configuration of the EHEA, were developed in three levels of performance. On the one hand, the university institutions, which had to face drastic changes, and on the other, the governmental authorities that had to regulate those changes and promote a new context where the quality, the mobility, the employability and the teacher careers are in the center of the model. The operative goals were adopt a transparent system of comparable degrees, implement a system based on three cycles (degree postgraduate and doctorate), develop the European Credit System (ECTS), promote the mobility; boost European cooperation for the assurance of Quality and promote the European dimension in the curriculum. In may of 2015, European Commission was published a document $(E C ; 2015)$ and suggest the achievments of Bolonia and its cuantitative and cualitative limits or disadvantages. It was divided in six áreas the limits and benefits. One is the structure of degrees and skills, the second the system was to guarantee the quality, the third the social dimensión of higher education, the fouth the long life learning, the fith the employability and the sixth the internalization and mobility. Although twenty years have passed since the Bologna Plan was signed, it can not be asserted that the project cycle is complete. Among these shortcomings for this Plan to be operational in all participating countries, we can highlight that the main initiatives need to be consolidated: formative mobility, credit transfer, accreditation standards, certification and recognition of competences. In the same way, second generation projects have yet to be defined: the social agenda of the Bologna, inclusion, equity, employability, lifelong learning and the transformation of teaching and learning practices. In Spain, The balance was positive despite the limits, and the results has been an advance. However, different authors such as Michavila (Michavila, F., et al; 2015; 2018), Nuñez C (2015) and other reports as the European Commission (2018), European Commission (2019) or the CRUE (Conferencia de Rectores de las Universidades Españolas) and emphasize that we must continue to focus on building quality culture, adapting the teaching-learning process, developing skills of the new industry drivers (digitalation, globalization...), changes in the employability and the links between Hihger Education Institution, The Industrial, Goverment and the Sociaty.

\subsubsection{The Develop of skills and competences at the European Higher Education Area.}

Higher Education faced an inevitable global opening with the creation and implementation of the EHEA, which demanded to incorporate new elements and new roless for the agents. The EHEA represented and will represent the greatest innovation in higher education and encourages universities to adapt them activities to the future of the new Knowledge Society and Digital Society. The new stage between 2010-2020 in the strategic conceptual framework for European Cooperation promoted the items related to this entrepreneurial approach to higher education institutions. The creation of a European credit transfer system, 
Ted talks as a simulation tool in a higher education for the learning process and improvement students' motivation : an academic practice with students of the Degree in Business Intelligence.

in order to facilitate the mobility and make equivalences between degrees carried out in different countries, was one of the great changes. The learning context became an ecosystem where the student performs learning activities -in the classroom and outside the classroom- with theoretical and practical lessons and is evaluated. With those new ways of doing, the European countries places in the center of the discussion-model the role of the student. Boths linked The University Education with the Professional World.

In Spain, the RD 1125/2003, the indications of the Agency National of Evaluation and Accreditation, made necessary the incorporation of the concept of competences. According to the RD1393/2007 and the RD861/2010 our titles will be designed based on objectives and competencies. Within these competences, there are several types -generic and transversal competences-. "The curricula leading to a degree must (...) have in the center of their objectives the acquisition of skills by students, expanding, without excluding, the traditional approach based on content and teaching hours. (...) The new organization of the teachings will increase the employability of undergraduates (...)". Certainly students and teachers participating in these projects. Mobility, academic results, competitive research projects and papers are examples of indicators, the research made and its impact, the successful of the teaching-learning process. Since 2000, other indicators that showed the successful of Bolonia as the number of universities that offered congress and programs about education and innovation. In conclusion, the connection to the professional world and expectation, the goals of employability highlight, the relevance of the competences and to adapat these professional and academic competences.

In 2012, ANECA published the Support Guide for the elaboration of the official university Degrees and Master in which defines competence as "the set of knowledge, skills, attitudes that are acquired or developed through coordinated training experiences, which are intended to achieve functional knowledge that efficiently respond to a task or problem of daily life and professional, requiring a process of teaching and learning". With this new approach, the role of the student in their self-.learning is fundamental and the student is the main protagonist in the achievement of the objectives. Since then, there are many practices related to different methodologies that have been implemented in Spanish universities by the faculty. Studies carried out by the Economics and Social Council in its report on professional competences and employability in 2015, as well as other reports (WEF, 2018; Michavila, 2015) reveal the gap between the needs of the labor market and the profiles of graduates. The evidence on the effectiveness of problem-based learning compared with more traditional approaches in higher teaching and the conclusions of this repost Its about the necessity to develop new softskills for the digital challenge and new jobs. With the application of creative and innovative teaching methodologies, the intention is to increase student motivation and enhance these competencies. In this paper we shall focus on the 
methology that permits to increase motivation and develop professional and academic skills. Nevertheless, Spanish universities have clearly contributed to social improvement (Sanchidrian R, Garzon D.; 2013). Apart, the CRUE observatory provides statistics and analyses the key competences and indicators of Spanish universities and promote, in our opinion, an increasing awareness and sensibility in universities concerning measurement.

\subsubsection{The TEDxtalks as a proactive tools to improve the competences: our project.}

The needs of improve the skills of the digital students and their motivation have changed the methods of teaching and assetsments. The gamification and simulations are examples of best practices (Axelrold, R. 2006; Chin, J. et al; 2009; Marcelo, C. 2015, Zabalza; 2011; Rodrigez et al; 2018; Hoidn, S. et al; 2014). This simutalion of TEDxtalks for students is a tools to adapt the students profiles at the market needs. For this reasons, This project dediced to use a new methology in a transversal subject and do a prospective after to do it in a future at specialist subjects.

The on-line resourses for teaching are incorporated to the new courses and to the informal learning. One of this resources is the TEDxtalks; This tool was created to disseminate scientific results of great researchers. It has now become a system of scientific and social dissemination, used to improve formal and informal learning. Internet, the new Social Technology Network and platform as YouTube had been managed to open new channels to facilitate massive learning, just as it happened with MOOCs, TEDs and University Channels, blogs and platforms. The TEDxtalks has its own effective rules and shows the skills of the great speakers. For that, TEDxtalks offers scientists and other experts a platform to provide scientific information directly to millions of people around the world. The mayority of teachers and students use them as a reactive tools to learn as a informal methodology but in this innovation practice we dediced to use them to improve the skills.

In this practice the students in a team group had to choose a topic, research about it, prepare the contend of the TEDxtalks and do a simulation as an speaker in a real situation of performance. In this casce, It's a cross-subject at the Degree in Business Intelligence and Doble Degree Business Intelligence and Business Administration -6 ECTS- and first course. The students dedicated the $30 \%$ of the hours to this activities and the assestment was for $30 \%$. The number of the students are 45 -national and foreign students-. The main goal had been improve the self motivation, skills and knowledge of the students and prospective about the impact of this practice to use it in the second course in a specific subject -Financial accounting-. At the end the assetsment of this simulation had be done by a quantitative - success indicators- and qualitative -perception studio-.

At the Table 1.1 Its possible to find the skills to promote divided in six classification. 
Ted talks as a simulation tool in a higher education for the learning process and improvement students' motivation : an academic practice with students of the Degree in Business Intelligence.

Table 1.1. Skills and competences of this innovation project.

\begin{tabular}{|c|c|c|c|c|c|}
\hline \multicolumn{5}{|c|}{ Simulations students TEDxtalks: skills and compentences asset ment } \\
\hline $\begin{array}{c}\text { Capacity to } \\
\text { looking for } \\
\text { information and } \\
\text { analyses the } \\
\text { social impact of } \\
\text { proyect. }\end{array}$ & $\begin{array}{c}\text { Capacity to research } \\
\text { international studies } \\
\text { and report and } \\
\text { promote evidence } \\
\text { based scientific. }\end{array}$ & $\begin{array}{c}\text { Responsibility, } \\
\text { Leadership and } \\
\text { Planning skils. Team } \\
\text { work, planification of } \\
\text { activities, focus on } \\
\text { excellence }\end{array}$ & $\begin{array}{c}\text { Ethics and } \\
\text { sustentability sociaty } \\
\text { values }\end{array}$ & $\begin{array}{c}\text { Communication } \\
\text { skills: no verb and } \\
\text { effective } \\
\text { communication skills }\end{array}$ & $\begin{array}{c}\text { Creative } \\
\text { presentation } \\
\text { and ability to } \\
\text { impact }\end{array}$ \\
\hline
\end{tabular}

Font: Authors compile

The strategy has been defined in three phases that are briefly described below:

Phase 1: Project Design. This stage took place in the first month. The objective has been to create the appropriate atmosphere and train with the following activities:

- $\quad$ Choose the skills and competences (table 1.1).

- Designe the workshop and activities to develop them.

- Adap the TEDxtalks rules for the simulation. Same caracteristics but the perfomer was defined for a team ( 2 or 3 people) and create the assetsment and rubric.

Phase 2: Initial Implementation Pilot Project. The length of time is until the end of the semester. The aim is to make aware the student. To do this, the strategy puts the focus on five pillars: Introduce the TEDxtalks as a toold to learn and improve the skills, students training, selft motivation, research and performance (techniqs and final presentation). The student selected the team and had 20 days to chose 3 topics. In a tutorial session defined the advantages and disadvantages of each topic with the teacher advisor. At the end, They selected the topic that motivates them to prepare an excellence work -Table 1.2-. The topic will be interesting, serious and pioneer with social impact. The students -8 academic hours and 25 external time- prepare the content and the surprise effect of the effectiveness communication. They had Class-session about the rules of the TEDxtalks and the communication skills (written, oral and non verbal communication). At the end, prepared the performance at the theatre salon and did the performance to students and teachers.

Phase 3: First, the evaluation of results (quality and quantitative indicator) and design the new strategic challenges to use the TEDxtalks at Financial Accounting subject. Second, a prospective report -to prepare cuestionaries to first course students (Introduction to financial accounting) to evaluate the perception for using this simulation the next course-. 
Table 1.2. Topics select for students.

\begin{tabular}{|l|l|}
\hline 1.Blockchain: easy to undertand. & 9 Data Ethics: hope for an ethical world \\
2.He for her: new propoursal & 10.Feel D Music. \\
3.Ethics and Business analytics & 11.Big Data and advertining : new performance and indicators. \\
4.Social network and big Data & 12 Security and privacy on internet \\
\hline 5 Artificial intelligence: new capacity-new computer & 13 The magic of the music as a therapy. \\
6 Researh and Longevity & 15 Bilingualism and trilingualism and the open mind \\
7 Music and emotional intelligence & \\
8 Music and the impact in the sences & \\
\hline
\end{tabular}

Font: Authors complile

\subsection{Results, conclusions and prospective.}

The objective is to evaluate this teaching experience based on a Skills that the TEDxtalks promotes. At the end of the innovative project we evaluated the results obtained (Table 2.1). On the one hand, we evaluate the academic results that improved substantially. On the other hand, we conducted a survey to the students to assess their own perception. The $100 \%$ of the students answered the questionnaire and the $85 \%$ of the prospective study.

Table 2.1 Main results.

\begin{tabular}{|c|c|}
\hline $\begin{array}{l}\text { ACADEMIC RESULTS: } \\
\checkmark \text { The } 100 \% \text { of the students participated on time throughout the } \\
\text { schedule. } \\
\checkmark \quad \text { Only } 10 \% \text { were delayed in the deadline. } \\
\text { All the students exceeded the assetment and improved their } \\
\text { performance. The } 50 \% \text { obtained outstanding results. }\end{array}$ & $\begin{array}{l}\text { MOTIVATION RESULTS } \\
\checkmark \quad \text { The } 100 \% \text { of the students introduced their hight level motivation } \\
\text { to participate in this activities. } \\
\text { The factor that motivated students are to do a TEDxtalks and its } \\
\text { external implications, the team work, improve the } \\
\text { communication skills, the challenge of reduces the fear to be an } \\
\text { speaker. } \\
100 \% \text { Recommended to do in specific subject and not only in } \\
\text { cross-subject. }\end{array}$ \\
\hline $\begin{array}{l}\text { PERCEPTION RESULTS: } \\
\checkmark \quad 100 \% \text { students saw the TEDxtalks as much to learn as to } \\
\text { entertain themselves. } \\
\text { Every students valued highly the working of the six } \\
\text { competences and considered that they had improved deeply in } \\
\text { analytical skills, creativity, communication skills, leadership } \\
\text { and ethics. } \\
\text { Only the } 30 \% \text { of students considered that they had improved in } \\
\text { search of information. } \\
\text { The } 80 \% \text { considered the important to measurement the time that } \\
\text { students spent in this activity. } \\
\checkmark \quad \text { The } 20 \% \text { would do it as an extra-academic activity. }\end{array}$ & $\begin{array}{l}\text { PROSPECTIVE RESULTS (Specific subject: introduction of finantial } \\
\text { subject) } \\
\checkmark \quad \text { The mayority of students use The TEDxtalks as a system to } \\
\text { learn and other to enjoy. } \\
\text { The first skills that they consider the TEDxtalks develop are } \\
\text { communicative skills, the second creative to present an idea, } \\
\text { the third skills about looking for information and the syntesis } \\
\text { and apllied the knowledge to practical situation. } \\
\text { They consider the ethics, hosnesty and human sense are the } \\
\text { values less considers. }\end{array}$ \\
\hline
\end{tabular}

Font: Authors compile

The conclusions about it, revealed considerable concentration in opinion among the advantages to use the TEDxtalks as a proactive tools to improve skills. The two groups of students with regard to the skills needed, the skills received and the additional training needed. The prospective study recommend to use this method at Financial accounting $\left(2^{\circ}\right.$ course of Business Administration Degree) and It's possible to use this practice in other subject when the goal is to improve the communication skills and other competences. This research contributes to the scarcel empirical research on the use of TEDxtalks as an 
Ted talks as a simulation tool in a higher education for the learning process and improvement students' motivation : an academic practice with students of the Degree in Business Intelligence.

effective learning tools in cross-subject and the motivation of students to use it in specific subject in higher education envirioment.

\section{References}

Axelrod, R. (2006) Advancing the afrt of simulation in the social sciencies. Rennard J. (Ed) Handbook of research on nature-inpired computing for economics and management. 90-99.

Word Economic Forum (2018)

Ching, J., Dukes R.;Camson, W (2009). Assestment in simulation and gaming:A review of the 40 years. Simulation\&Game. Vol 40. 533-468

European Commission (2015) The European Higher Education Area in 2015: Bologna Process Implementation Report". Retrieved from https://eacea.ec.europa.eu/nationalpolicies/eurydice/content/european-higher-education-area-2015-bologna-process-implementationreport_

European Commission (2018).Promoting the relevance of Higher Education. Retrieved from https://publications.europa.eu/en/publication-detail/-/publication/59d3a999-84b9-11e8-ac6a$\underline{01 \text { aa75ed71a1 }}$

European Commission (2019).Study to evaluate the progress on Quality assurance systemin the area of Higher Education in the member states and on cooperation activities at European level. Retrieved from https://publications.europa.eu/en/publication-detail/-/publication/80cf98f3-1e0111e9-8d04-01aa75ed71a1

Hoidn, S. and K. Kärkkäinen (2014), "Promoting Skills for Innovation in Higher Education: A Literature Review on the Effectiveness of Problem-based Learning and of Teaching Behaviours", OECD Education Working Papers, No. 100, OECD Publishing, Paris, https://doi.org/10.1787/5k3tsj671226-en.

Marcelo, C. York, C. Mayor, C. (2013). Enseñar con tecnologías digitales en la Universidad. Comunicar, Vol 45. Pp 117-124. Retrieved from http;//dx.dol.org/10.3916/C45-2015-12

Michavila, F., Martinez, J.M., Merhi, R. (2015). Comparación Internacional del Sistema Universitario Español.Crue Universidades Españolas. Monografías.13-33.

Michavila, F., Martinez, J.M., Martín-González, M, García-Peñalvo, F.J., Cruz-Benito .J. (2018). Empleabilidad de los titulados universitarios en EspañaProuecto OEEU. Education in the Knowledge Sociaty (EKS). Vol. 19, nº1 .21-39.

Nuñez, C.E. (2015). Strong State and Weak Universities, the long-term roots of the Spanish university system problems. Revista de historia de las Universidades Vol. 18, nº 1, 97-116.

Rodríguez Gómez, R. (2018). Dos décadas del proceso de Bolonia. Revista mexicana de investigación educativa, Vol.23(76), 7-14. 
Sanchidrian, R. Garzón L. (2013). Leadership in Higher Education. A Successful Case of Entrepreneurial Universities with a Sustainable Curriculum Project. GiKA.

Zabalza, M. (2011). Metodología docente. Revista de Docencia Universitaria, Vol. 9, 75-98. 